\section{Rethinking Reverence for Life}

\author{
Mike W. Martin \\ Chapman University \\ Orange, California
}

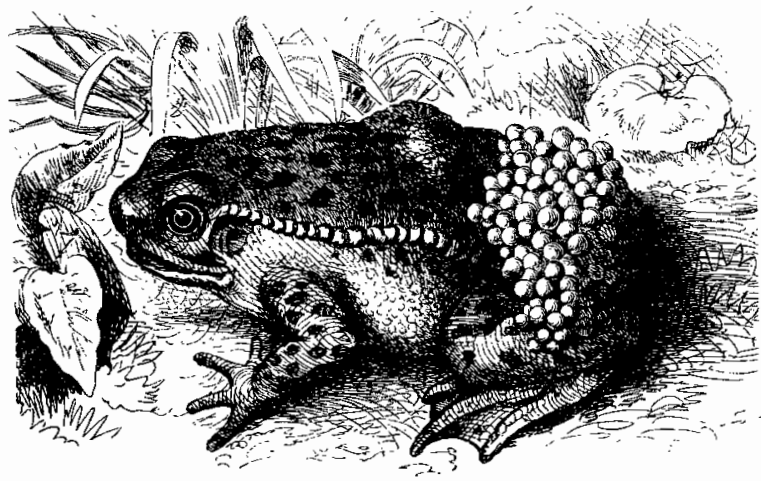

Albert Schweitzer's ethics of reverence for life is more complex and interesting than first appears. It contains themes relevant to contemporary environmental ethics, including a virtue-ethics approach that emphasizes personal responsibility and tolerance, empathy for living organisms, and the fundamental unity of life. Not surprising, then, Schweitzer has recently been acknowledged for pioneering a biocentric (lifecentered) ethical theory. ${ }^{1}$

At the same time, Schweitzer's ethic has four unpalatable features: pantheism, anthropomorphism, excessive subjectivity, and guilt mongering. I trace these features to the metaphysical framework in which Schweitzer develops his ideal of reverence for life. I also show how the framework can be set aside while retaining much of the spirit and substance of his ethics. My aim is not to defend his ethics, but to interpret it and show its contemporary relevance.

\section{Unity of Life (without Pantheism)}

Theories of environmental ethics differ according to their conceptions of what things have inherent worth, that is, value in themselves and independently of human

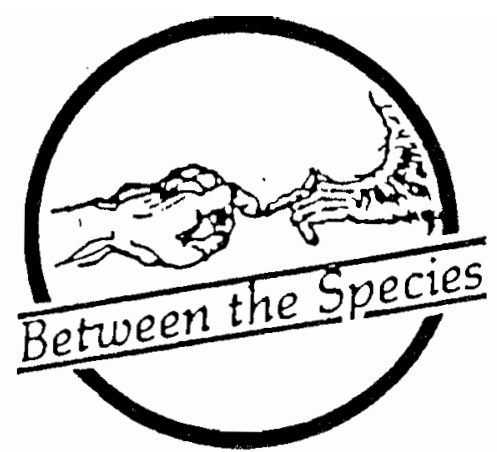

desires and appraisals. ${ }^{2}$ According to human-centered (anthropocentric) ethics, only humans have inherent worth. Other natural objects have value only because humans value them, whether instrumentally or intrinsically. Things have instrumental value when they are useful to humans. For example, drinkable water, breathable air, and natural medicines have instrumental value because they contribute to the further good of health. Things have intrinsic value when they are pleasing because of their aesthetic or symbolic properties, as when we value wilderness areas and bald eagles because of their beauty and community significance.

Non-human-centered ethics locates inherent worth in natural things in addition to humans. In particular, biocentric ethics locates inherent worth in living things. Although Schweitzer did not explicitly use the distinction between inherent worth versus intrinsic value, it is clear he defended a biocentric ethics that locates inherent value in all living things: all life is "sacred" and "something possessing value in itself." (C 57)

Theories of environmental ethics also differ according to whether they are individualistic or holistic in approach. Thus, biocentric theories are individualistic when they locate inherent worth in particular organisms. They are holistic when they locate inherent worth in communities of life (ecosystems), in types of life (species), or in the environment as a whole. Schweitzer

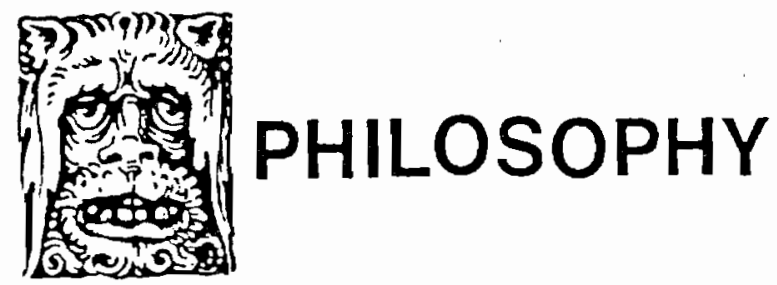


bridges the dichotomy between individualistic and holistic bioethics. He insists that each living organism has inherent worth, yet at the same time his primary theme is the unity of life. This moral and spiritual unity is ultimately unfathomable, which is why he calls his theory ethical mysticism. This is an "active mysticism" that inspires commitments to further life, by contrast with "passive mysticism" centered on emotional experiences of identity with God or nature.(C 79)

Schweitzer renounced metaphysics in the sense of a search for an ultimate purpose of the universe that gives meaning to humanity.(C 73) The meaning of our lives is created through personal commitments, not discovered through cosmic speculation. Nevertheless, Schweitzer did hold a metaphysical theory in the sense of a view of ultimate reality, and that theory forms the framework in which he develops his theme of life's unity. He maintained a faith in a universal, infinite, and creative Will-to-live.(C 79) Much of the time this faith remained in the background, but it surfaced periodically, as in this passage: "Reverence for life means to be in the grasp of the infinite, inexplicable, forward-urging Will in which all Being is grounded." $(\text { C 283 })^{4}$

Schweitzer was influenced by Arthur Schopenhauer's voluntarist metaphysics according to which ultimate reality is will. "Behind all phenomena" there is will-tolive, and each organism constitutes part of that will-a will to both survive and to develop according to its natural tendencies.(C 308, 282) Unlike Schopenhauer, Schweitzer was deeply religious, though his religious convictions were highly unorthodox. They hovered somewhere near pantheism but were closer to biotheism - the view that God is manifested in and constituted by all life. ${ }^{5}$ By the time he wrote The Philosophy of Civilization Schweitzer was most likely an agnostic concerning supernatural beings (God, angels, souls), even though he continued to use conventional religious language when speaking as a minister and theologian. The divine is immanent in nature rather than transcendent to it: "The Essence of Being, the Absolute, the Spirit of the Universe, and all similar expressions denote nothing actual... The only reality is the Being which manifests itself in phenomena."(C 304)

Schweitzer's metaphysics has some interest. It shares a kinship with the worldviews of Spinoza, Hinduism, Buddhism, and Native American religions. Perhaps its greatest value lies in bridging Christian orthodoxy and naturalistic worldviews. Even so, I wish to set the metaphysics aside, at least the part of it which suggests there is a cosmic and semi-deified Will-to-live that can be said to act creatively in the universe. What then remains of the theme of life's moral unity?

Abandoning Schweitzer's metaphysics need not mean rejecting his ethics. ${ }^{6}$ I offer three preliminary observations. First, Schweitzer is the first to remind us that the core of a moral outlook can survive intact after being freed from the worldview in which it was first developed. In The Quest of the Historical Jesus he argues that Jesus held a false eschatology which anticipated the end of the world during his lifetime. That eschatology led to some unjustified value judgments, including a pessimistic renunciation of human society as a mere overture to the approaching kingdom of God. Nevertheless, Schweitzer embraces Jesus as a moral paragon whose ideal of love can be transplanted from the metaphysics in which it was initially formulated. I suggest the same is true of Schweitzer's ideal of reverence for life.

Second, Schweitzer insists that ethics cannot be inferred from metaphysics. In particular, the ideal of reverence for life cannot be derived from observing nature's spectacle of killing. Schweitzer prides himself on being "absolutely skeptical" about cosmic purposes while maintaining an optimistic and life-affirming attitude.(C 76) As I have suggested, he is not as metaphysically skeptical as he claims, since he continues to assume there is a unified and universal Will-to-live manifested in all life. Nevertheless, setting aside his metaphysics is consistent with the spirit of his largely empirical-oriented "natural ethic."(L 235)

Third, Schweitzer's metaphysics distorts some of his most important ideas. For example, in the next section I show how his central argument for the ideal of reverence for life is cogent only when freed from its metaphysical moorings. Even the central theme of the unity of life is better appreciated without relying on metaphysical speculations. When Schweitzer urged in his sermons, "Wherever you see life-that is yourself!," he evoked responses that were not dependent on his parishioners being pantheists.( $R$ 115)

We might understand the unity-of-life theme as drawing together a rich variety of familiar experiences and facts, including the following.

1. Compassion is a natural response to the suffering of other people and animals, a response which Schweitzer felt in extraordinary degrees from childhood on. ${ }^{7}$ He was ahead of his time in calling 
for humane treatment of animals in medical experiments and food production.(C 318)

2. We have benefited in many ways from animals, including the suffering inflicted on animals in medical experiments. Because of this "a new and special relation of solidarity has been established between them and us."(C 318)

3. Caring in the animal world is often strikingly analogous to human caring, and both have a biological origin. Just as humans care for their children, many species of animals care for their offspring and even for animals outside their kinship groups. In citing such examples Schweitzer anticipates the insights of sociobiologists about the genetic basis for human and nonhuman caring.(L 237-9, C 224-6)

4. With many individual animals we can enter into reciprocal caring relationships, indeed "friendship with animals." 8

5. Plants, animals, and humans interact in complex chains of interdependency. We are united with nature in that our very survival depends on those interdependencies being sustained.(L 237)

6. We experience moments of awe in which we maryel at the sheer existence of life and the infinite diversity of living creatures.( $(\mathrm{114}-5)$

7. We also experience moments of humility when we understand that humanity is but one of millions of fragile life forms and not the final goal of the universe.(L 226)

8. The competition and killing defining the food chain are not the only significant aspects of nature. Equally noteworthy is the cooperation and tolerance which have evolved as part of the shared struggle to survive.(C 260)

The moral implications of these experiences need to be sorted out and considered separately. Nevertheless, they have a cumulative impact in moving us toward a sense of oneness with nature of a sort aptly conveyed in the phrase "reverence for life"--reverence for life as a whole, as well as for particular organisms.

\section{Empathy with Life (without Anthropomorphism)}

An adequate ethical theory, according to Schweitzer, meets several general criteria.

1. It provides a unifying perspective on moral values.(C 105)
2. It focuses on self-perfection, where complete selfperfection implies bringing our lives into a positive relationship with the universe and with life as a whole.(C 57, 296)

3. It is optimistic in the sense of evoking positive commitments on behalf of civilization, which consists in progress of all kinds, and it evokes steady and enthusiastic commitment by tapping into our most basic sources of motivation.(C xiii, 107)

4. It avoids metaphysical assumptions about the ultimate purposes of the universe.(C 76)

Surveying the history of ethics, Schweitzer argues that the ethic of reverence for life meets these criteria better than competing theories. His arguments, however, turn substantially on personal factors about how the ideal of reverence for life brings selffulfillment through service to others.(C 255) Alternative moral theories generate greater motivation and self-fulfillment for some individuals, and from a modern pluralistic point of view it is misguided to call for "a single ideal of civilized man."(C 47) In any case, something more is needed to justify reverence for life than the four general criteria.

The "something more" is Schweitzer's famous willto-live argument. (C 308-311, 0 155-158, L 227-229). The argument is easily ridiculed because it seems to depend on attributing human features to all living things. Anthropomorphic attributions permeate Schweitzer's writings, such as when he says that all organisms suffer, ${ }^{9}$ that a beetle is capable of "rejoicing in the sun like you,"(R 115) and that each organism "strives" to achieve its highest perfection.(C 282) But anthropomorphism is especially prominent in the will-to-live argument, and it makes the argument seem utterly naive, as the following summary indicates.

I am a will-to-live, with desires for self-preservation, self-perfection, pleasure, happiness, and avoiding pain. All other organisms have these same desires, feelings, and aspirations: "As in my own will-to-live there is a longing for.... pleasure, with dread of annihilation and wider life and for.... pain; so is it also in the will-tolive all around me."(C 309) Therefore, since I value my life I must (in consistency) value all other life, "for I shall know that it longs for fulness and development as deeply as I do myself."( L 230)

The obvious rejoinder is that most organisms do not have desires like mine, whether for gaining pleasure and avoiding pain or for self-survival and selfperfection. Pleasure and pain are conscious states, and 
plants and protozoa lack the neurological structures for having or desiring conscious states. Moreover, desiring self-survival and self-perfection implies having a conception of oneself, a self-consciousness, that plants and most animals lack. Even ascribing a will-to-live to plants and lower animals seems anthropomorphic insofar as a "will," at least in one literal sense, implies conscious intentions, desires, and beliefs.

How can we explain Schweitzer's seemingly naive anthropomorphism? As a physician and scientist, he was well aware that plants and lower animals lack the requisite neurological structures for consciousness. Clearly he was influenced by Goethe and other romantics who in their poetry personified nature, but how could a well-trained scientist be so apparently credulous in responding to that influence? ${ }^{10}$

Much of the explanation is his metaphysics. If each organism is literally part of a universal Will-to-live, and if the basic features of that universal will are uniform in all living organisms, then anthropomorphism is virtually inevitable, especially if we begin by reflecting on our own will-to-live. This tendency to anthropomorphize, however, is blocked once we set aside the metaphysics. There is little temptation to make literal ascriptions of human properties to algae and protozoa if they are no longer regarded as instantiations of a universal and personified will to live.

Another part of the explanation, however, is that Schweitzer may not have been as naively anthropomorphic as first appears. ${ }^{11}$ We can construe his anthropomorphic images as metaphors designed to evoke empathy with other life, rather than as literal ascriptions of human features to nonhuman organisms. Whether or not this was his primary intention, it invites a more serious examination of the will-to-live argument. Let us strip away the anthropomorphic images, retaining only the idea of a will-to-live understood as a literal reference to genetically-driven instincts to survive and develop. The following argument emerges. $(\mathrm{O}$ 155-8)

1. Will-to-Live Thesis: "I am life that wills to live in the midst of life that wills to live."

2. Definition: My will to live is defined by instinctive tendencies to survive and develop.

3. Self-Affirmation Thesis: When I am healthy and sincere towards myself, I feel reverence for my will to live: I affirm my will-to-live, as defined in (2), as having inherent worth, and I devote myself to its expression, preservation and development.
4. Analogy: All other organisms have similar tendencies to survive and develop.

5. Empathy Thesis: I experience empathy with other life as I reflect honestly, dwelling on its similarity to my life.

6. Life-Affirmation Thesis: My empathy generates sympathy, caring, and a "compulsion" (a strong desire and felt obligation) to approach other life with the same reverence I feel for my life.

7. Conclusion: Reverence for life is a fundamental virtue that consists in "preserving life, promoting life, developing all life that is capable of development to its highest possible value" and in not "destroying life, injuring life, repressing life that is capable of development."

This argument is phenomenological or experiencebased. It proceeds by reflecting on our experiences of our instincts to survive and develop, our affirmation of our lives inherent in those instincts, and our experience and knowledge of those same instincts in other life. Notice also that the conclusion is a statement about a virtue, not a rule of conduct. To be sure, reverence for life is a mandatory virtue, a virtue that we ought to cultivate and that embodies obligations. But it is a character trait, a desirable attitude and disposition, rather than a principle of action per se.

This interpretation captures Schweitzer's insistence that ethics is a product of reasoning that reveals how our attitudes toward all life should be "of a piece with" attitudes toward ourselves.(L 230) It also captures his conviction that reverence for life is a natural expression of our will-to-live: "I can do nothing but hold to the fact that the will-to-live in me manifests itself as will-to-live which desires to become one with other will-to-live."(C 312). Our inclination to contribute to other living things expresses our desires for selffulfillment. We achieve "self-perfection through selfdevotion": self-fulfillment through exercising and expanding our natural capacities for empathy and sympathy for other life.(C 255)

The crux of the argument is the experience of empathy of a kind that inspires sympathetic concern for other life. This appeal does not make Schweitzer's ethics human-centered. Empathy is a response to other life as like us, but just as much a response that we are like other life, at the fundamental level of shared drives to survive and develop.

Schweitzer does not use the word "empathy" as frequently as "sympathy," but he does use various 
phrases to convey the idea. Reverence for other life begins when one experiences that life "in" one's own life, "feeling as one's own all the circumstances and all the aspirations of the will-to-live."(O 157, C 311) Empathy does not imply sharing the feelings and desires of the organisms we empathize with, and hence it is not based on anthropomorphic ascriptions of feelings and desires to all life. It is also broader than compassion, which is a sympathetic response to the suffering of sentient creatures.(C 311) Empathy means identifying with other life, at least at the level of shared tendencies to survive and develop within the range of possibilities made possible by circumstances and genetic inheritance. But the identification must involve a degree of concern sufficient to develop naturally into sympathy and caring.

Is the will-to-live argument sound? Not in the sense of providing a knock-down proof. Nevertheless, the argument is far from being silly. It is provocative and relevant to contemporary environmental ethics. Here are some of the problems which need to be confronted in assessing the argument.

Contrary to premise (5), not all of us experience empathy for all life forms. What then? Schweitzer can only try to generate, intensify, and expand empathy. One way is by asking us to reflect further on similarities between our will-to-live and other organisms' instincts to survive and develop. Another way is to urge us to recall occasions when we felt moments of union and kinship with nature (of the sort listed earlier). Still another way is to use anthropomorphic metaphors to evoke empathy and sympathy.

Even if we do come to the point where we experience a "compulsion" to feel empathy with all other life, as premise (6) suggests, perhaps that compulsion should be resisted. Desires and feelings of obligations can be misguided. Just because they are natural does not mean they are justified. Thus, even if (6) states a fach, there is a contestable move to the valuestatement in (7) about a worthy ideal of character. The move involves an "is-ought" gap: If there is a compulsion to feel reverence for life, how does that establish that we ought to cultivate it, or that it is the most fundamental virtue? Still, if we do come naturally to experience a strong desire to revere life, this experience is certainly relevant to the conclusion. It bears on matters of personal identity, integrity, and fidelity to our experiences of unity with life.

Questions about personal identity return us to premises (1) and (2): Does our will to survive and develop define us in some basic way? Schweitzer insists the most "elemental" (basic, immediate) discovery is of ourselves and other life as sharing a willto-live whose essence is to survive and develop. $\mathrm{He}$ chastises Descartes for beginning with an empty abstraction, "I think, therefore I am." "To think means to think something," and the most primordial thought to emerge from introspection is that I am a will to live amidst other wills to live.(O 156) Yet, introspection can only uncover what our conceptual schemas predispose us to uncover. Descartes' conceptual framework predisposed him to 'discover' a thinking substance, whereas Schweitzer's metaphysical framework predisposed him to discern a will to live among other such wills. At the same time, perhaps premises (1) and (2) will survive in some form within a contemporary sociobiological framework that does not rely on Schweitzer's metaphysics.

Is premise (3) true? Does sincerity toward ourselves lead us to affirm our will-to-live at the "elemental" level indicated? "Sincerity" implies honesty with oneself, but it also implies being "true to oneself" and maintaining "fidelity with oneself."'(C 78, 282; L 230) It implies a fundamental self-affirmation by bringing to consciousness an instinctive desire to survive and develop.(O 157) The deepest level of self-affirmation does seem to be an outgrowth of instinctive will to live. This bedrock affirmation is not based on specific features of ourselves, nor even our general capacities as humans. If it is as primordial as Schweitzer suggests then it gives some cogency to the will-to-live argument.

The will-to-live argument omits, however, that we value ourselves and other humans for additional reasons beyond our instinctive will-to-live. We affirm ourselves at many levels, including at the level of specific characteristics (our interests, accomplishments, relationships, virtues, etc.) and generic properties (our general human capacities). In these respects we are not comparable to all other life, and our full worth turns on things beyond the instinctive drives we share with all life. That is relevant in understanding how to act when confronted with conflicts between our lives and others, or between killing one life to save another, topics to which I turn next.

In short, there are difficulties with the will-to-live argument, but nevertheless the argument carries some force, especially when its appeal to empathy is combined with the unity-of-life experiences mentioned earlier. It may turn out that we do discover within us an 
empathetic desire to identify with and care for other life, a desire that is as natural ("healthy," "sincere") and deeply-rooted ("elemental") as our self-affirmation. If so, it seems likely that empathy will be a key ingredient in any non-human-centered ethics. ${ }^{12}$

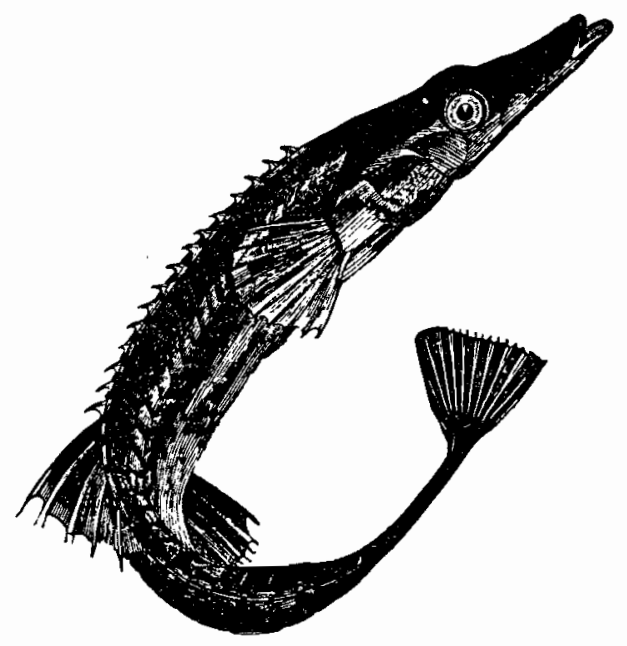

\section{Moral Guidance (versus Arbitrariness)}

In saying that all life deserves reverence, Schweitzer did not claim that all life has equal value, and he was usually careful not to assert moral equality among all living things (whatever that would mean). At the same time, he consistently refused to rank the value of different species and types of life. The ethical person, he tells us, "does not ask how far this or that life deserves one's sympathy as being valuable, nor, beyond that, whether and to what degree it is capable of feeling. Life as such is sacred to him."(C 310) Yet, as Schweitzer also emphasizes, we cannot live outside nature's cycle of killing. Even to breathe or to take a walk is to kill micro-organisms, and often we must save one life by destroying others. What guidance, then, does he offer about killing versus preserving life?

Schweitzer tells us we must kill only when "necessary" and that determining when killing is necessary involves "subjective" and "arbitrary"
decisions.(O 236, L 233) As it stands, the idea of arbitrary decisions about killing is a dead end (no pun intended). What led to this impasse?

Schweitzer offers two reasons against ranking life forms, each of which is interesting but inconclusive.(O 235) First, ranking encourages abuses and callousness, such as dismissing some forms of life, whether "primitive peoples" or endangered species, as being worthless and destroyable at whim. This is a genuine problem, but it can be resolved by exercising good moral judgment based on sound reasoning and caring. Second, he insists that rankings cannot be justified in terms of differential roles of life forms in the universe, since we lack knowledge of any such cosmic roles. Perhaps, however, we might justify at least rough guidelines about the differential treatment of life forms by reapplying Schweitzer's own appeals to empathy, as I will suggest in a moment.

I believe that the real reason why Schweitzer refuses to rank life forms or offer priority rules is his metaphysics. If each organism is a sacred part of a universal and semi-deified Will-to-live, then it would seem blasphemous to grade or rank them, either as individuals or as members of species. It would also follow that killing any life is sacrilegious. If we set aside the metaphysics, are there perhaps other aspects of Schweitzer's ethics that provide some guidance about when killing is justified?

Schweitzer boldly set forth a virtue (or character) ethics before it became fashionable to do so. Now, according to long-standing objections, virtue ethics as too vague and provides insufficient guidance; it encourages subjectivity and even arbitrariness. Aristotelians offer a two-fold reply. First, the virtues do provide significant guidance, especially when they are carefully sorted out and applied. Aristotle sorted the virtues according to particular areas of conduct and feeling where they function as a reasonable guide between excess and defect. Contemporary virtue ethicists have developed more subde approaches to clarifying the meaning and application of specific virtues. Second, while rules play a role in moral conduct, they are not enough. The essential factor in difficult situations is good judgment-practical wisdom. Good judgment is a product of proper upbringing, breadth of experience, and nuanced moral sensitivity, rather than a mechanical application of rules.

Because Schweitzer does not openly follow Aristotle's lead, he is especially vulnerable to the charge 
of being excessively subjective or even vacuous. ${ }^{13} \mathrm{He}$ fails to make prominent a conception of good judgment in making decisions, and at least at first glance he tries to reduce all virtues to one: reverence for life. In doing so his ethics may gain inspirational force, but it loses the fine-tuning of Aristotelian approaches.

In reply, we can note that the surface simplicity of Schweitzer's ethics belies an underlying complexity. $\mathrm{He}$ is not trying to reduce all virtues to one. Instead, like most virtue-ethicists, he seeks an organizing framework for the virtues. Ethics needs a focus in a central ideal of character, since "the mere giving of a list of virtues and duties is like striking notes at random on the piano and thinking it is music."(C 105) But nor do all virtues dissolve into one grand virtue of reverence for life. On the contrary, the ideal of reverence for life yokes together (without blurring) specific virtues, including forgiveness, self-control, tolerance, justice, and especially compassion, gratitude, and sincerity with oneself (honesty with and fidelity to oneself) ${ }^{14}$

These virtues can and do conflict, creating familiar moral dilemmas whose resolution requires good judgment. Indeed, any one of these virtues can point in different directions. Compassion requires supporting sentient life, but it can also require ending it: "In many ways it may happen that by slavish adherence to the commandment not to kill compassion is less served than by breaking it. When the suffering of a living creature cannot be alleviated, it is more ethical to end its life by killing it mercifully than it is to stand aloof." 15 Passages like this imply a conception of good moral judgment in exercising the virtues, even though that judgment cannot be neaty encapsulated in rules.

While Schweitzer sometimes claimed that reverence for life is a comprehensive moral principle, in other places he denied it. His theory is primarily about individual rather than social ethics.(C 245) Thus he could write: "My idea of reverence for life is not meant to guide the African in striving for his own and his nation's freedom. It is meant to get him to deal with more than himself in the spiritual world...."16 This is a revealing statement. Reverence for life implies a deepened respect for human rights, (C 328) but understanding the complex interplay of rights in international affairs will require an exploration of more specific moral principles than his ideal of reverence for life can provide by itself. ${ }^{17}$ Similarly, we might think of reverence for life as the primary ideal for individuals in morally relating themselves to life while acknowledging that matters of public policy concerning the environment need to involve more focused rules.

Why did Schweitzer leave so much leeway for individual interpretations in applying the ideal of reverence for life? Although he claims to have uncovered the ultimate foundation for ethics, we can view him as responding to the needs of a particular time-though a time not altogether unlike our own. Writing in the aftermath of World War I, he saw a crisis in Western civilization. The crisis was manifested in the devaluation of human life but rooted in the forces of mass society. Most people, he charged, are "lost in the mass" and prevented from working out their own convictions, whether due to overwork, overspecialization, or control by governments, corporations, and churches.(C 17) To counterbalance these forces, each of us must engage in personal reflection on moral values and respect the similar efforts of others. Accordingly, an adequate ethics must be flexible, open, and tolerant. It will be individualistic and overcome traditional ethicists' "downright fear of what cannot be subjected to rules and regulations."(C 291) A creative ethics of altruism will have a "fluid indefiniteness" that embraces innumerable avenues for caring.(C 166, 320)

This spirit of flexibility is attractive, but can an environmental ethic reasonably forgo all rankings of life forms? I do not see how. Perhaps we should beed Schweitzer's advice to avoid abstract cosmological rankings, but we do and must implicitly use rankings when we make decisions about the differential treatment of species in cases of conflicting interests. Indeed, Schweitzer himself sometimes implies there are good reasons for valuing organisms differentially according to the forms of life possible for them. He clearly implies that sentient creatures have a moral status unlike that of plants and nonsentient animals. He devotes special attention to arguing against killing sentient creatures for pleasure: bull fighting, cock fighting, and hunting for sport. ${ }^{18}$ And he inveighs against misuse of sentient animals in medical experiments and in teaching science. No similar pronouncements are made about experiments on plants. Even if we avoid saying sentient animals have greater inherent worth than other animals, clearly the implication is that sentient animals make special claims on us (as do humans).

Does Schweitzer's ethical theory leave any room for making the rankings he disavows? Return to the first premise in the will-to-live argument: "I am life 
which wills to live, in the midst of life which wills to live." Even if we grant that the most basic form of selfaffirmation is affirmation of our will-to-live, and even if we agree that at this level we share a kinship with all life, we also discover dissimilarities between our will to: live and other organisms once we turn from introspection to inspection of the world. Depending on the organism, the dissimilarities will be striking (as with plants and lower animals) or less striking (as with higher mammals). Rarely will they justify eradication of a species (as with the polio and AIDS viruses), but they will justify the commonsense conviction that humans have greater inherent worth than algae. They will also justify cherishing chimpanzees more highly than chiton, because of the former's more sophisticated mental and social life.

Does reverence for life permit eating sentient animals or does it require vegetarianism? The refusal to make differential judgments about life forms prevents us from grasping this question as urgent in the way that Schweitzer himself did toward the end of his life. ${ }^{19}$ If cows and cabbage are equally sacred, why should eating the one raise greater moral qualms than eating the other? Once we recognize moral differences between sentient and nonsentient life, especially as we attend to the suffering inflicted on sentient creatures in modern meat production, the issue becomes important within an ethics of reverence for life, even though that ethic does not by itself settle the issue.

Also consider Schweitzer's conduct. He helped a wounded osprey by choosing to kill fish to feed it. Although he insisted that such choices are arbitrary, most of us see a good reason in the unique features of the osprey and in its rarity, compared to the abundance of fish. We justify special effor ts to preserve endangered species, rather than treating each living organism as on a par with every other. Even if we share Schweitzer's hesitation to make abstract rankings of life forms, we can understand his stories about saving one animal by sacrificing others as parables of good judgment in "necessary" killing.

What, after all, is necessary killing? Schweitzer suggests we can kill nonhuman life

a. in self-defense,

b. as an inevitable part of legitimate activities, such as when we crush microorganisms by going for a walk, and

c. in order to save human lives, as when a physician kills dangerous microorganisms.(C 316)
These pronouncements qualify as moral rules, however rough. ${ }^{20}$ As such they call for justification, presumably in terms of the greater value of a human life compared with dangerous microorganisms.

Rethought along these lines, Schweitzer's ideal of reverence for life remains somewhat vague (or creatively open), but hardly vacuous. After setting aside his metaphysics, we can maintain the spirit of flexibility and personal discretion in his ethics while taking into account the forms of life possible for them. Schweitzer repeatedly insisted that we must stop killing thoughtlessly, that we must think before we kill. He should have insisted that we think well, that we exercise good moral judgment--but he implied as much.

\section{Responsibility (without Guilt Mongering)}

Contemporary ethics is preoccupied with complex moral dilemmas. Schweitzer, by contrast, was preoccupied with motivation and with finding an ethics that inspires moral commitment and enthusiasm.(C 299) Reverence for life is an ideal of character that "penetrates unceasingly and in all directions a man's observation, reflection, and resolutions" in devotion to life.(C 316) It is absolute in the sense that it can never be fully achieved, given that to be alive is to participate in some killing.(L 232) Yet that very absoluteness evokes a higher moral pitch in everyday emotion and conduct.

This emphasis on high moral aspiration was distorted by his occasional preoccupation with guilt. I am guilty, he says, each time I kill any living thing, no matter what my motive: "Whenever I in any way sacrifice or injure life, I am not within the sphere of the ethical, but I become guilty, whether it be egoistically guilty for the sake of maintaining my own existence or welfare, or unegoistically guilty for the sake of maintaining a greater number of other existences or their welfare."(C 325) For Schweitzer, then, "necessary" killing does not mean justified killing. Nor does it mean killing which is wrong but excusable, so as remove guilt. To kill is to be culpable. We are "murderers" when we kill a mosquito and "mass murderers" when we kill bacteria.(C 316-7)

These are extraordinary claims! Admittedly, they have a certain authenticity insofar as they flow from Schweitzer's metaphysics. ${ }^{21}$ If each organism is sacred, then killing it is tantamount to desecrating the sacred, rendering one guilty. But consistency is one thing; cogency is another. Schweitzer's metaphysics is 
a recipe for guilt mongering, which is my final reason for setting it aside.

Does setting the metaphysics aside diminish the high demands contained in reverence for life? There is some danger, of course, that the demands may be too great. Schweitzer placed enormous pressure on himself and seemed to find his feelings of guilt a helpful source of motivation. ${ }^{22}$ Most people, however, would be crushed by comparable feelings of guilt.

Surely we can respond to a call for greater responsibility for life without being drawn into excessive guilt. In its core meaning, responsibility means trying to act responsibly and being morally accountable, that is, susceptible to being called to account for our conduct in terms of good moral reasons. ${ }^{23}$ When those reasons are sound and sufficient, killing is justified and (at least often) no guilt is involved. In particular, there is no guilt-none whatsoever-when a physician like Schweitzer killed bacteria by sterilizing surgery instruments or when patients take antibiotics. Nor is there guilt when we eat vegetables and nonsentient animals (leaving aside the controversy over eating sentient animals).

That does not mean we should never feel bad when we justifiably participate in killing. Regret is often appropriate. Regret is the appropriate emotion when we reasonably wish we did not have to take life, by contrast with guilt for unjustified killing. Regret can be mild or intense, and it can be accompanied by strong feelings of sadness, grief, and even horror. (Think of euthanizing a beloved pet whose suffering from cancer can no longer be lessened in other ways.) In addition to being focused on specific acts of killing, regret can be a general response to our immersion in the cycle of killing.

If we reassert common sense in justifying "necessary" killing, have we abandoned the spirit of reverence for life? Surely not. Reverence for life includes reverence for our own lives, as manifested in justifiable selfdefense. Understandably and admirably, Schweitzer wanted to avoid an ethic of expediency in which human concerns automatically override the interests of other life forms. But in doing so he established a misleading dichotomy between "ethical and necessary," such that taking life is unethical even when necessary to protect other life.(C 325) This dichotomy is inconsistent with his own insistence that the ethical includes reverence for oneself as manifested in self-defense and selfdevelopment. It is also inconsistent with his belief that devotion to other life sometimes requires killing for its sake. To be consistent, Schweitzer should say that the ethical includes necessary killing, not contrasts with it.

To conclude, Schweitzer's metaphysical vision contributed to the boldness with which he set forth a biocentric ethics over half a century before most philosophers began to struggle with his issues. That metaphysics distorts some of his central ideas, yet the key elements in his ethics survive intact after his metaphysics is set aside. Those elements include unity of life, empathy for other living organisms based on shared instincts, a flexible virtue-guided perspective focused in a (complex) ideal of reverence for life, and responsible commitment to furthering life while being sensitive to differences among life forms. ${ }^{24}$

\section{Notes}

${ }^{1}$ Although I disagree with substantial parts of their interpretations of Schweitzer, the following philosophers provide insightful discussions: J. Baird Callicott, "On the Intrinsic Value of Nonhuman Species," in Bryan G. Norton (ed.), The Preservation of Species: The Value of Biological Diversity (Princeton: Princeton University Press, 1986), pp. 153-155; John Kleinig, Valuing Life (Princeton: Princeton University Press, 1991), pp. 47-56; Lawrence E. Johnson, A Morally Deep World (New York: Cambridge University Press, 1991), pp. 134-141; and Joseph R. DesJardins, Environmental Ethics: An Introduction to Environmental Philosophy (Belmont, CA: Wadsworth, 1993), pp. 147-151. An additional indication of renewed interest in Schweitzer is inclusion of his writings in several widely used texts: Tom Regan and Peter Singer (eds.), Animal Rights and Human Obligations, 2d ed. (Englewood Cliffs: Prentice Hall, 1989); Susan J. Armstrong and Richard G. Botzler (eds.), Envimnmental Ethics (New York: McGraw-Hill, 1993); Louis P. Pojman (ed.), Environmental Ethics: Readings in Theory and Application (Boston: Jones and Bartlett, 1994).

${ }^{2} \mathrm{Cf}$. the definitions of these terms given by Joseph R. DesJardins in Environmental Ethics, pp. 144-146.

${ }^{3}$ Parenthetical page references to Schweitzer are as follows. C: The Philosophy of Civilization (Buffalo: Prometheus Books, 1987). L: "The Ethics of Reverence for Life," in Christendom, I (1936): 225-239. 0: Out of My Life and Thought, trans. A. B. Lemke (New York: Henry Holt and Company, 1990). R: Reverence for Life, trans. Reginald H. Fuller (New York: Harper and Row, 1969).

${ }^{4}$ Especially illuminating is Gabriel Langfeldt, Albert Schweitzer: A Study of His Life and Thought, trans. Maurice Michael (London: George Allen and Unwin, 1960).

${ }^{5}$ Of course, Schweitzer's optimism is polar-opposites to Schopenhauer's thoroughgoing pessimism. Nevertheless 
Schopenhauer's influence is unmistakable in passages where the entire world (not just life), and especially inorganic crystals and snowflakes are said to manifest the will-to-live (C 282, $R$ 115). Such passages are also ubiquitous in Arthur Schopenhauer, The World as Will and Representation, trans. E.F.J. Payne, Vol. II (New York: Dover Publications, 1966).

${ }^{6}$ Cf. James F. Doyle, "Schweitzer's Extension of Ethics to All Life," Journal of Value Inquiry, 11 (1977), p. 45.

${ }^{7}$ Albert Schweitzer, Memoirs of Childhood and Youth, trans. C.T. Campion (New York: The Macmillan Company, 1961), pp. 27-31.

${ }^{8}$ Walter Bahr (ed.), Albert Schweitzer: Letters 1905-1965, trans. Joachim Neugroschel (New York: Macmillan Publishing Company, 1992), p. 350.

${ }^{9}$ Walter Bahr (ed.), Albert Schweitzer: Letters. 1905.' 1965 , p. 336.

${ }^{10}$ See Albert Schweitzer, Goethe: Five Studies, trans. Charles R. Joy (Boston: Beacon Press, 1961).

11 Schweitzer was quite capable of the aesthetic distancing involved in making humorous ascriptions of human features to animals. See The Story of My Pelican (London: Souvenir, 1964).

${ }^{12}$ After criticizing Schweitzer, J. Baird Callicott makes a suggestive appeal to "bio-empathy" in "On the Intrinsic Value of Nonhuman Species," pp. 156-162. My interpretation of Schweitzer brings their views closer together. I also see Schweitzer-like appeals to empathy in John A. Fisher, "Taking Sympathy Seriously: A Defense of Our Moral Psychology Toward Animals," in Eugene C. Hargrove (ed.), The Animal Rights/Environmental Ethics Debate: The Environmental Perspective (Albany: State University of New York Press, 1992), pp. 227-248; Kenneth E. Goodpaster, "On Being Morally Considerable," The Journal of Philosophy 75 (1978): 308-325; and Paul Taylor, Respect for Nature (Princeton: Princeton University Press, 1986).

13 These charges are more justified with regard to Schweitzer's cousin, Jean-Paul Sartre. There are some striking parallels between Schweitzer's "elemental" ethics of sincerity with oneself and Sartre's existentialist ethics of honesty with oneself. Unlike Sartre, however, Schweitzer retains a conception of objectively-defensible values.

14 Cf. Henry Clark, The Ethical Mysticism of Albert Schweitzer (Boston: Beacon press, 1962), pp. 38-52.

${ }^{15}$ Albert Schweitzer, Indian Thought and Its Development, trans. Mrs. Charles E. B. Russell, (Gloucester, Mass: Peter Smith, 1977), p. 83.

16 Walter Bahr (ed.), Albert Schweitzer: Letters, 1905 1965, p. 287.
${ }^{17}$ Schweitzer occasionally discusses rights, as noted by Antje Bultmann Lemke in David C. Miller and James Pouilliard (eds.), The Relevance of Albert Schweitzer at the Dawn of the 21st Century (Lanham: University Press of America, 1992), pp. 83-84. Making human rights more prominent, however, might have helped him avoid the great blemish on his career: His support for colonialism and his paternalism toward Africans. See The Primeval Forest, trans. C.T. Campion (New York: Pyramid Books, 1961), p. 99. Also see Manuel M. Davenport, "The Moral Paternalism of Albert Schweitzer," Ethics, 84 (1974): 116-127.

18 Albert Schweitzer, The Animal World of Albert Schweitzer, trans. and ed., Charles R. Joy (Boston: Beacon Press, 1950).

${ }^{19}$ Schweitzer became a vegetarian only in his late eighties, four decades after initially formulating his philosophy of reverence for life. James Brabazon, Albert Schweitzer: A Biography (New York: G. P. Putnam's Sons), p. 463.

${ }^{20}$ Schweitzer also occasionally formulates rough rules of conduct toward persons, such as the principle that good fortune obligates.(C 321) Cf. Herbert Spiegelberg, "Good Fortune Obligates: Albert Schweitzer's Second Ethical Principle," Ethics, 85(1975):227-234. Ultimately, however, these rules are grounded in virtues and ideals of character. See my essay, "Good Fortune Obligates: Albert Schweitzer on Gratitude and Philanthropy," manuscript submitted for publication.

21 There is also an authenticity in passages like the following: "By helping an insect when it is in difficulties, I am only attempting to cancel part of man's ever new debt to the animal world."(C 318) Without his metaphysics, however, the compensation is at most symbolic.

22 Louise Jilek-Aall, Working with Dr. Schweitzer: Sharing his Reverence for Life (Blaine, WA: Hancock House, 1990), pp. 189-190.

${ }^{23}$ John Kleinig, Valuing Life, p. 55.

${ }^{24}$ I thank Kurt Bergel and Alice R. Bergel for their helpful comments on an earlier draft of this paper.

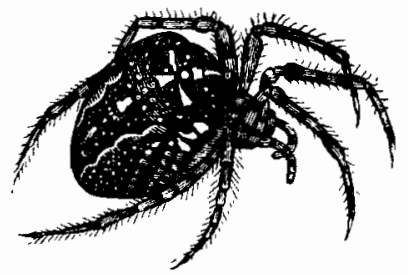

